\title{
Influence of Volume of Nutrient Agar Medium on Development of Colonies of Marine Bacteria*)
}

\author{
Wilfried Gunkel $\left.{ }^{* *}\right)$, Galen E. Jones, and Claude E. ZoBell \\ Scripps Institution of Oceanography, University of California, \\ La Jolla, Calif., USA
}

\begin{abstract}
Plating the heterogeneous bacteria occuring naturally in samples of raw sea water with volumes of molten nutrient agar exceeding $10 \mathrm{ml}$ reduces the number of colonies which develop. Plate counts on replicate samples of sea water are generally highest and results are more nearly reproducible when $10 \mathrm{ml}$ of nutrient agar is used rather than volumes ranging randomly from 5 to $30 \mathrm{ml}$. Although other factors are involved, the adverse effects of volumes of nutrient agar appreciable larger than $10 \mathrm{ml}$ are attributed primarily to the slower cooling rates during conventional plating procedures. When nutrient agar medium at $42^{\circ} \mathrm{C}$ was poured into pyrex Petri dishes at room temperature $\left(22-24^{\circ} \mathrm{C}\right), 10 \mathrm{ml}$ of the medium cooled to $30^{\circ} \mathrm{C}$ in about one minute, whereas from about 5 to 24 minutes were required for 20 to $50 \mathrm{ml}$ of the medium to cool from $42^{\circ} \mathrm{C}$ down to $30^{\circ} \mathrm{C}$. Many marine bacteria are injured by being subjected to temperatures higher than $30^{\circ} \mathrm{C}$, the extent of the injury being a function of time. Therefore, it is of paramount importance that agar be cooled to $42^{\circ} \mathrm{C}$ prior to pouring. The rate at which agar medium cools in plates is influenced by the composition and temperature of the table top on which the plates rest.
\end{abstract}

\section{Zusammenfassung}

Bei der Bestimmung der Anzahl Bakterien in frisch genommenen Seewasserproben mit dem Plattengußverfahren reduziert eine Agarmenge von über $10 \mathrm{ml}$ die Anzahl sich entwickelnder Kolonien. Die erhaltenen Zahlen sind im allgemeinen am höhsten und die Ergebnisse am besten reproduzierbar, wenn genau $10 \mathrm{ml}$ des Nähragars benutzt wird im Gegensatz zu unbestimmten Mengen zwischen 5 und $30 \mathrm{ml}$. Obgleich auch andere Faktoren eine Rolle spielen, wird der ungünstige Einfluß von Agarmengen, die merklich größer als $10 \mathrm{ml}$ sind, in erster Linie den langsameren Abkühlungsraten während des üblichen PIattenguBverfahrens zugeschrieben. Wenn Nähragar von $42^{\circ} \mathrm{C}$ bei Raumtemperatur $\left(22-24^{\circ} \mathrm{C}\right)$ in Pyrex-Petrischalen gegossen wurde, kühlten $10 \mathrm{ml}$ in ca. $1 \mathrm{~min}$. auf $30^{\circ} \mathrm{C}$ ab, während 5 bis $24 \mathrm{~min}$. gebraucht wurden, um Agarmengen von 20 bis $50 \mathrm{ml}$ von $42^{\circ} \mathrm{C}$ auf $30^{\circ} \mathrm{C}$ abzukühlen. Viele marine Bakterien werden geschädigt, wenn sie Temperaturen ausgesetzt werden, die über $30^{\circ} \mathrm{C}$ liegen, wobei das Ausmaß der Schädigung von der Einwirkungszeit abhängt. Deswegen ist es überaus wichtig, daß der Agar vor dem Gießen auf $49^{\circ} \mathrm{C}$ gekühlt wird. Die Abkühlungsrate des Agarmediums in den Platten wird von der Beschaffenheit und der Temperatur der Tischoberfläche, auf der die Platten stehen, beeinflußt.

*) Contribution from the Scripps Institution of Oceanography, University of California, La Jolla, California.

**) Biologische Anstalt Helgoland, Helgoland, Germany. 


\section{Introduction}

Although pour plate methods generally detect far fewer bacteria in sea water or sediment samples than the direct microscopic observations of cells (Collins and Kipling, 1957; Jannasch, 1958; Jannasch and Jones, 1959; Kriss, 1959), pour plates yield useful information concerning bacterial populations occurring in marine environments. The colonies which develop on pour plates may provide viable cells or pure cultures for further study. In attempts to increase the total numbers and kinds of bacteria forming colonies, considerable effort has been devoted to improving pour plate media and methods.

The volume of nutrient agar used per plate by various workers is not uniform and, in most instances, is not even specified. "Standard Methods of the American Public Health Association" (1960) stipulates that not less than $10 \mathrm{ml}$ of liquefied agar medium at temperatures ranging from $43^{\circ}$ to $45^{\circ} \mathrm{C}$ shall be added per Petri dish. The "Manual of Methods of the Society of American Bacteriologists" (De Moss and BARD, 1957) recommends the use of from 10 to $15 \mathrm{ml}$ of agar medium per $100-\mathrm{mm}$ Petri dish. Volumes of nutrient agar varying from as little as $5 \mathrm{ml}$ to as much as $35 \mathrm{ml}$ have been used indiscriminately by many investigators, probably because the importance of a definite volume has not been stressed.

The following study was made to determine the effect of volume and temperature of nutrient agar medium on the development of bacterial colonies in the pour plate method for bacteria from the marine environment.

Samples

\section{Materials and Methods}

Sea water samples were collected with a J-Z sampler (ZoBel., 1941) at a depth of three meters from the end of the Scripps Institution pier (approximately 300 meters offshore). This area is subject to neither pollution nor dilution. During the sampling period the water temperature ranged from $13.4^{\mathrm{O}}$ to $17.5^{\circ} \mathrm{C}$. Shortly after collection the water samples were plated with different volumes of nutrient agar. For comparison with colony formation by the mixed flora in these samples of raw sea water, properly diluted suspensions of a laboratory culture of a marine bacterium, Serratia marinorubra (ZoBeLL and Upнaм, 1944) were used. This culture has been maintained in the laboratory since its isolation from the sea nearly 20 years ago.

\section{Medium}

The nutrient agar medium consisted of $5 \mathrm{~g}$ casein hydrolysate (NBC), $0.05 \mathrm{~g} \mathrm{~K}_{2} \mathrm{HPO}_{4}, 0.01 \mathrm{~g} \mathrm{FePO}_{4}, 15 \mathrm{~g}$ agar (Difco), $250 \mathrm{ml}$ distilled water, and $750 \mathrm{ml}$ aged sea water (salinity ca. $34 \mathrm{~g} / \mathrm{L}$ ). Following autoclave sterilization for 15 minutes at $121^{\circ} \mathrm{C}$, the $\mathrm{pH}$ of the medium was 7.4-7.6. Volumes were dispersed in screw-cap test tubes as follows: $5,10,15,20,30,40$ and $50 \mathrm{ml}$.

\section{Culture Methods}

Each dish was inoculated with $1.0 \mathrm{ml}$ of raw sea water or with a properly diluted suspension of S. marinorubra. The latter was grown in nutrient sea water broth at $26^{\circ} \mathrm{C}$ for 48 hours. At least two different dilutions of each sample of sea water or pure culture of suspension were plated; ten replicates 
for each dilution for each different volume of medium were employed. The medium, cooled to $42^{\circ} \mathrm{C}$ in a water bath, was poured into the inoculated dishes at room temperature $\left(22-24^{\circ} \mathrm{C}\right)$. The dishes inoculated with mixed marine microflora were incubated for 7 days at $18^{\circ} \mathrm{C}$. The colonies were counted with a Quebec colony counter.

\section{Temperature Measurement}

In order to determine the rates at which different volumes of agar medium cooled from $42^{n} \mathrm{C}$ to room temperature after being poured into culture dishes, some of the latter were equipped with a calibrated thermistor (Western Electric 14-B bead-type) connected to a Varians strip recorder. This provided for the continuous measurement of temperature of the poured agar with an accuracy of $0.1^{\circ} \mathrm{C}$.

\section{Results}

In one series of experiments (Table 1), from two to three times as many bacteria in samples of raw sea water formed colonies in Petri dishes poured with $10 \mathrm{ml}$ of agar medium as in dishes poured with 20 to $50 \mathrm{ml}$ of the medium. In another series of experiments (Table 2), only 17.6 per cent as many colonies developed from raw sea water in dishes poured with $50 \mathrm{ml}$ of agar medium as in dishes poured with $10 \mathrm{ml}$ of medium. During the first few days of incubation at $18^{\circ} \mathrm{C}$ almost as many colonies appeared in dishes poured with $5 \mathrm{ml}$ of agar medium as with $10 \mathrm{ml}$. The most nearly reproducible results were obtained when $10 \mathrm{ml}$ of agar medium was used.

Different volumes of the medium produced colonies of different kinds and characteristics. Generally, more pigmented colonies developed from raw sea water inocula in plates poured with $10 \mathrm{ml}$ of agar medium than in dishes

Table 1

Number of colonies counted per plate after 7 days' incubation at $18^{\circ} \mathrm{C}$ when $1.0 \mathrm{ml}$ of raw sea water (sample G19/59) was used to inoculate different volumes of agar medium poured at $42^{\circ} \mathrm{C}$. Also given ist the average growth index*) and the time in minutes required for the poured medium to cool from $42^{\circ} \mathrm{C}$ down to $30^{\circ} \mathrm{C}$

\begin{tabular}{|c|c|c|c|c|c|}
\hline \multirow{2}{*}{$\begin{array}{c}\text { Replicate } \\
\text { No. }\end{array}$} & \multicolumn{5}{|c|}{ Volume of agar medium in $\mathrm{ml}$} \\
\hline & 10 & 20 & 30 & 40 & 50 \\
\hline 1 & 102 & 31 & 24 & 79 & 39 \\
\hline 2 & 94 & 46 & 43 & 63 & 65 \\
\hline 3 & 134 & 46 & 42 & 33 & 51 \\
\hline 4 & 137 & 97 & 39 & 43 & 99 \\
\hline 5 & 108 & 78 & 64 & 84 & 69 \\
\hline 6 & 96 & 62 & 29 & 67 & 38 \\
\hline 7 & 85 & 31 & 49 & 42 & 33 \\
\hline 8 & 135 & 58 & 33 & 50 & 41 \\
\hline 9 & 122 & 38 & 41 & 30 & 30 \\
\hline 10 & 115 & 99 & 26 & 29 & 42 \\
\hline Average number & 112.8 & 56.9 & 38.3 & 52.0 & 43.0 \\
\hline Growth index & 100.0 & 50.4 & 33.9 & 46.1 & 38.1 \\
\hline Cooling time & 0.8 & 4.9 & 11.2 & 16.8 & 28.8 \\
\hline
\end{tabular}

*) The growth index is the per cent of the average number of colonies appearing in plates poured with $10 \mathrm{ml}$ of agar medium. 
Table 2

Number of bacterial colonies counted per plate after 7 days' incubation at $18^{\circ} \mathrm{C}$ when $1.0 \mathrm{ml}$ of raw sea water (sample G2/60) was used to inoculate different volumes of agar medium poured at $42^{\circ} \mathrm{C}$. Also given is the time in minutes required for the medium to cool in Petri dishes from $42^{\circ} \mathrm{C}$ down to $30^{\circ} \mathrm{C}$

\begin{tabular}{cccccc}
$\begin{array}{c}\text { Replicate } \\
\text { No. }\end{array}$ & 5 & \multicolumn{6}{c}{ Volume of agar medium in $\mathrm{ml}$} \\
& & 10 & 20 & 30 & 50 \\
\hline 1 & 333 & 234 & 160 & 142 & 19 \\
2 & 277 & 335 & 209 & 169 & 52 \\
3 & 303 & 346 & 121 & 244 & 65 \\
4 & 363 & 423 & 355 & 123 & 30 \\
5 & 361 & 376 & 128 & 146 & 23 \\
6 & 339 & 348 & 355 & 398 & 111 \\
7 & 247 & 358 & 226 & - & 100 \\
8 & 248 & 408 & - & - & 82 \\
9 & 260 & 305 & 237 & 252 & 75 \\
10 & 325 & 385 & 219 & 395 & - \\
Average number & 305.6 & 351.8 & 223.3 & 224.7 & 61.9 \\
Growth index & 86.9 & 100.0 & 63.6 & 63.9 & 17.6 \\
Cooling time & 0.3 & 0.8 & 4.9 & 11.2 & 28.3
\end{tabular}

poured with larger volumes of medium. Spreading colonies were more prone to appear in plates poured with the larger volumes of medium, probably due to the presence of more water of condensation. The smaller the volume of medium, the higher was the proportion of surface colonies that developed from raw sea water inocula; surface colonies were larger on the average than those that developed deeply embedded in the medium.

The most pronounced effect on plate counts of different volumes of agar medium appears to be related to temperature and the time required for different volumes of medium to cool when poured into plates under laboratory conditions. With the larger volumes of agar medium which cool more slowly, thermosensitive bacteria in raw sea water inocula are subjected to adverse temperatures for longer periods of time. Fig. 1 shows the cooling rates of different volumes of the medium poured at $42^{\circ} \mathrm{C}$ into $100-\mathrm{mm}$ Petri dishes at room temperature $\left(23^{\circ} \mathrm{C}\right)$. One $\mathrm{ml}$ of sea water at $18^{\circ} \mathrm{C}$ was introduced into the dish immediately prior to pouring the medium to simulate the effect of such an inoculum on temperature conditions. Whereas $10 \mathrm{ml}$ of medium cooled to $30^{\circ} \mathrm{C}$ in less than two minutes, $20 \mathrm{ml}$ and larger volumes remained above $30^{\circ} \mathrm{C}$ for approximately 5 to 25 minutes, and above $25^{\circ} \mathrm{C}$ for half an hour or longer. As pointed out by ZoBeLl and ConN (1940), many marine bacteria are injured by brief exposure to temperatures no higher than $30^{\circ} \mathrm{C}$. ZoBELL. (1959) found that from 18.7 to 78.1 per cent of the bacteria in certain samples of raw sea water were killed by being held for 10 minutes at temperatures of $30^{\circ}$ und $40^{\circ} \mathrm{C}$ respectively. Differences occur in the temperature sensitivity of bacteria from different depths and latitudes. There may also be seasonal differences.

Larger volumes of agar medium are less harmful for plating bacteria which tolerate temperatures within the plating range, that is $30^{\circ}$ to $42^{\circ} \mathrm{C}$. This is illustrated by data in Table 3 showing plate count results obtained with a laboratory culture of S. marinorubra. It grows best at $26^{\circ} \mathrm{C}$ and is not injured by holding at $35^{\circ} \mathrm{C}$ for 10 minutes. 


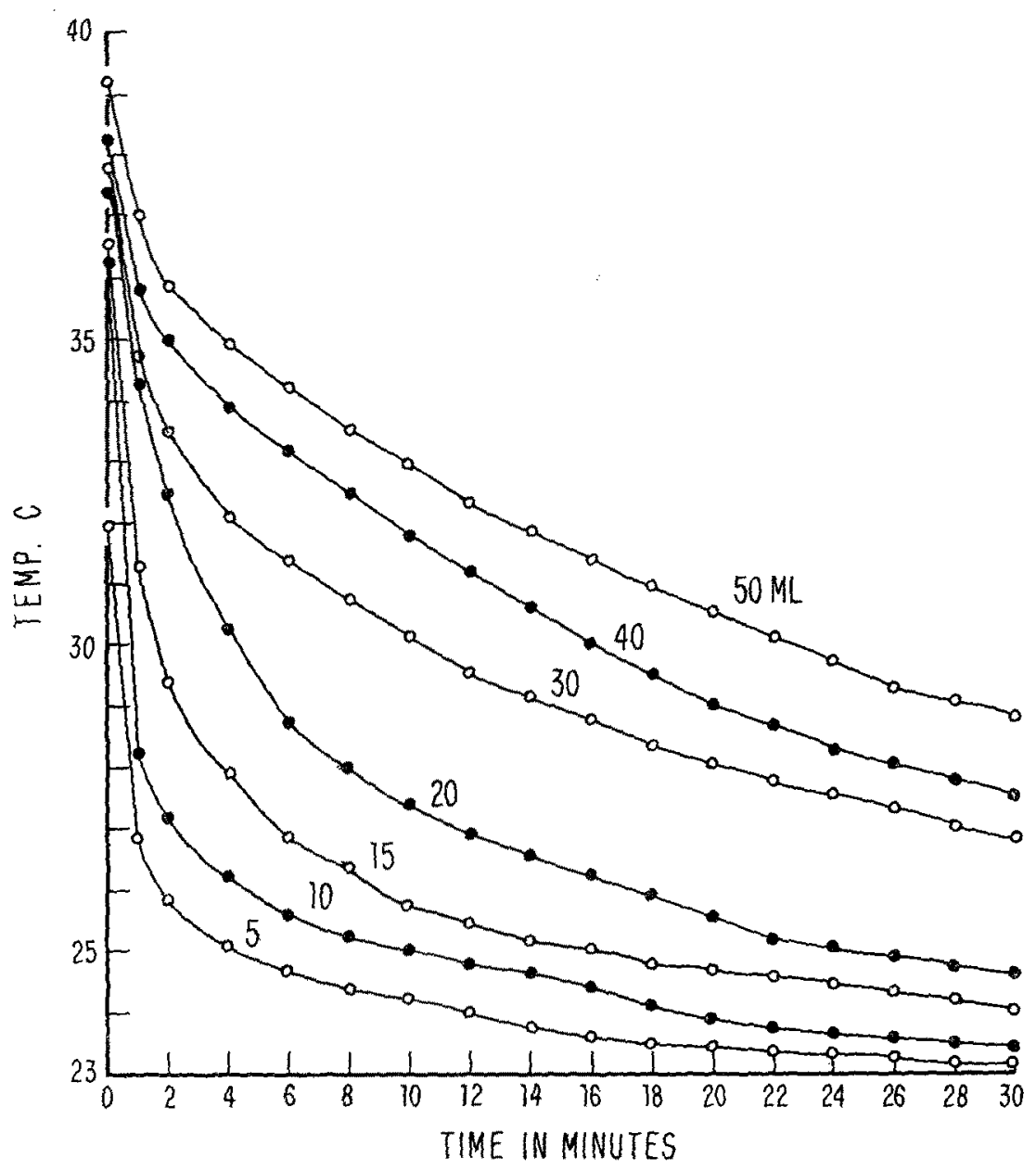

Figure 1. Temperature of nutrient agar after different periods of time when from 5 to $50 \mathrm{ml}$ at $42^{\prime \prime} \mathrm{C}$ was poured into $100-\mathrm{mm}$ pyrex Petri dishes at $23^{\circ} \mathrm{C}$

Table 3

Effect of volume of agar medium, poured at $42^{\circ} \mathrm{C}$, on number of colonies of Serratia marinorubra which developed from a dilute inoculum after 3 days' incubation at $26^{n} \mathrm{C}$.

\begin{tabular}{cccccc}
$\begin{array}{c}\text { Replicate } \\
\text { No. }\end{array}$ & \multicolumn{5}{c}{ Volume of agar medium in $\mathrm{ml}$} \\
& 10 & 15 & 20 & 30 & 50 \\
\hline 1 & 58 & 81 & 64 & 71 & 53 \\
2 & 82 & 80 & 80 & 59 & 69 \\
3 & 72 & 72 & 69 & 80 & 58 \\
4 & 64 & 68 & 68 & 86 & 68 \\
5 & 73 & 76 & 62 & 79 & 22 \\
6 & 70 & 78 & 50 & 73 & 55 \\
7 & 73 & 55 & 91 & 70 & 63 \\
8 & 87 & 61 & 64 & 63 & 65 \\
9 & 49 & 68 & 71 & 79 & 10 \\
10 & 66 & 79 & 51 & 63 & 74 \\
Average number & 69.7 & 71.8 & 67.0 & 72.3 & 55.7 \\
Growth index & 100.0 & 103.0 & 96.1 & 103.7 & 79.9
\end{tabular}


The rate at which agar medium cools is influenced by the heat-retaining properties of the culture dish and work bench. Data summarized in Fig. 2 show that agar medium cools more rapidly in glass Petri dishes resting on a stainless steel table top than on wood, polyvinyl plastic, or styrofoam. Regardless of the volume of agar medium poured at $42^{\circ} \mathrm{C}$, its temperature dropped more rapidly in pyrex Petri dishes than in plastic ones (Fig. 3).

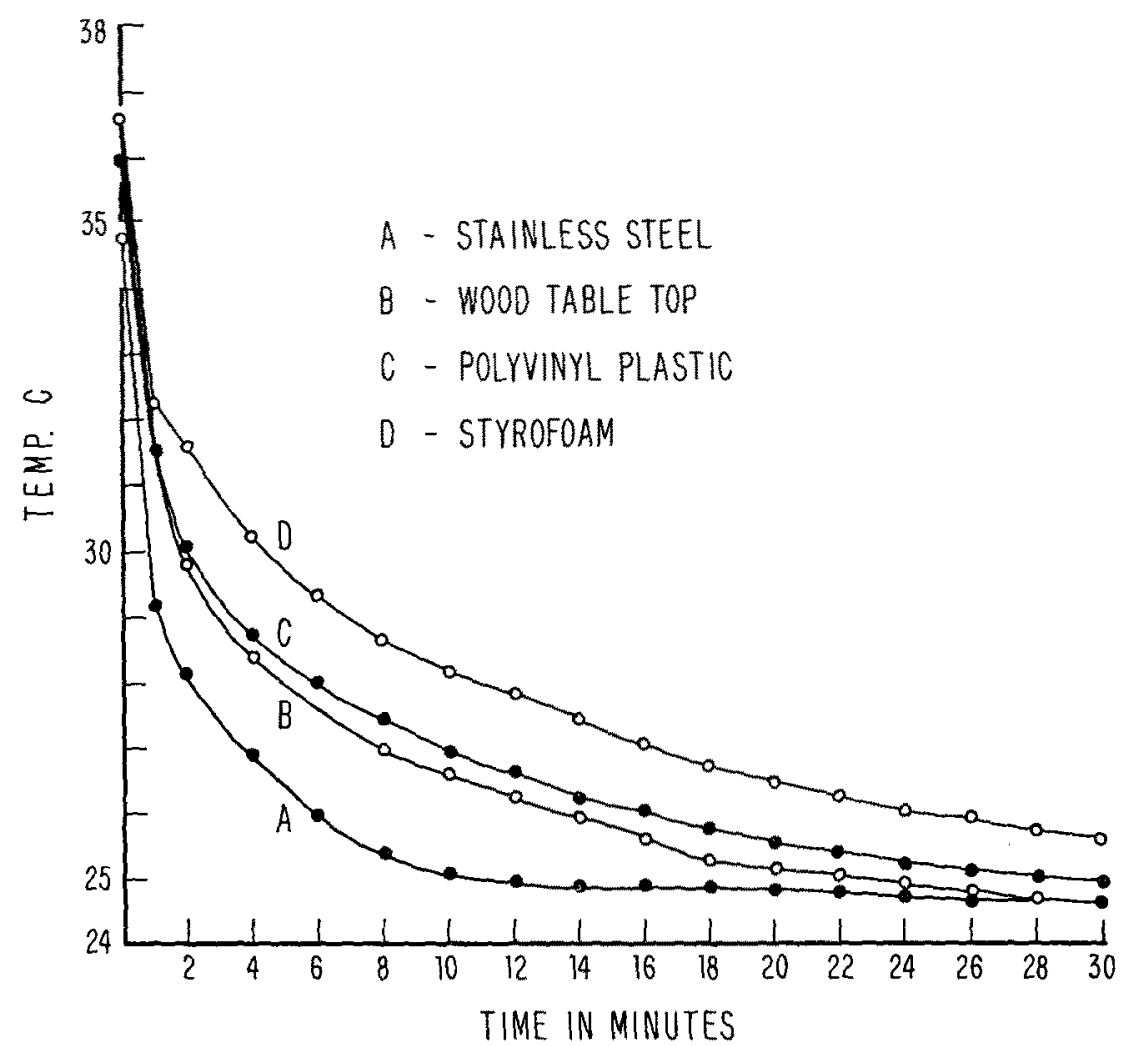

Figure 2. Temperature of nutrient agar after different periods of time when $10 \mathrm{ml}$ was poured at $42^{\circ} \mathrm{C}$ into 100 -mm pyrex. Petri dishes resting on surface of different composition at $25^{\circ} \mathrm{C}$

Also determined was the cooling rate of agar medium in Petroff and perscription bottles, which are often used for plating sea water and bottom sediment samples in the field. (ZoBeLL, 1946). An exact volume of agar medium was measured into $6-0 z$ perscription bottles which were then autoclaved and cooled to $42^{\circ} \mathrm{C}$ in a water bath.

After a thermistor was introduced to measure the temperature change. each bottle was inoculated with $1.0 \mathrm{ml}$ of sea water at $18^{\circ} \mathrm{C}$ and placed on its side to cool on a vinyl plastic table top. Some of the bottles were immersed to the neck in an ice-water bath for 1 to 25 seconds. When kept at room temperature without such immersion, $10 \mathrm{ml}$ of agar medium required nearly 10 minutes to cool from $42^{\circ}$ to $30^{\circ} \mathrm{C}$ (Fig. 4). Larger volumes of agar medium cooled even more slowly in bottles. Immersing the bottles in ice water increased the cooling rate substantially. Similar results were obtained with Petroff bottles. When bottles are used to plate thermosensitive bacteria, a 10-second 
immersion in ice water is recommended. This provides for cooling $10 \mathrm{ml}$ of agar medium to below $28^{\circ} \mathrm{C}$ in about one minute and results in the development of significantly more colonies. If immersed in ice water for much longer than 10 seconds, agar medium commences to solidify in the bottom of the bottles.

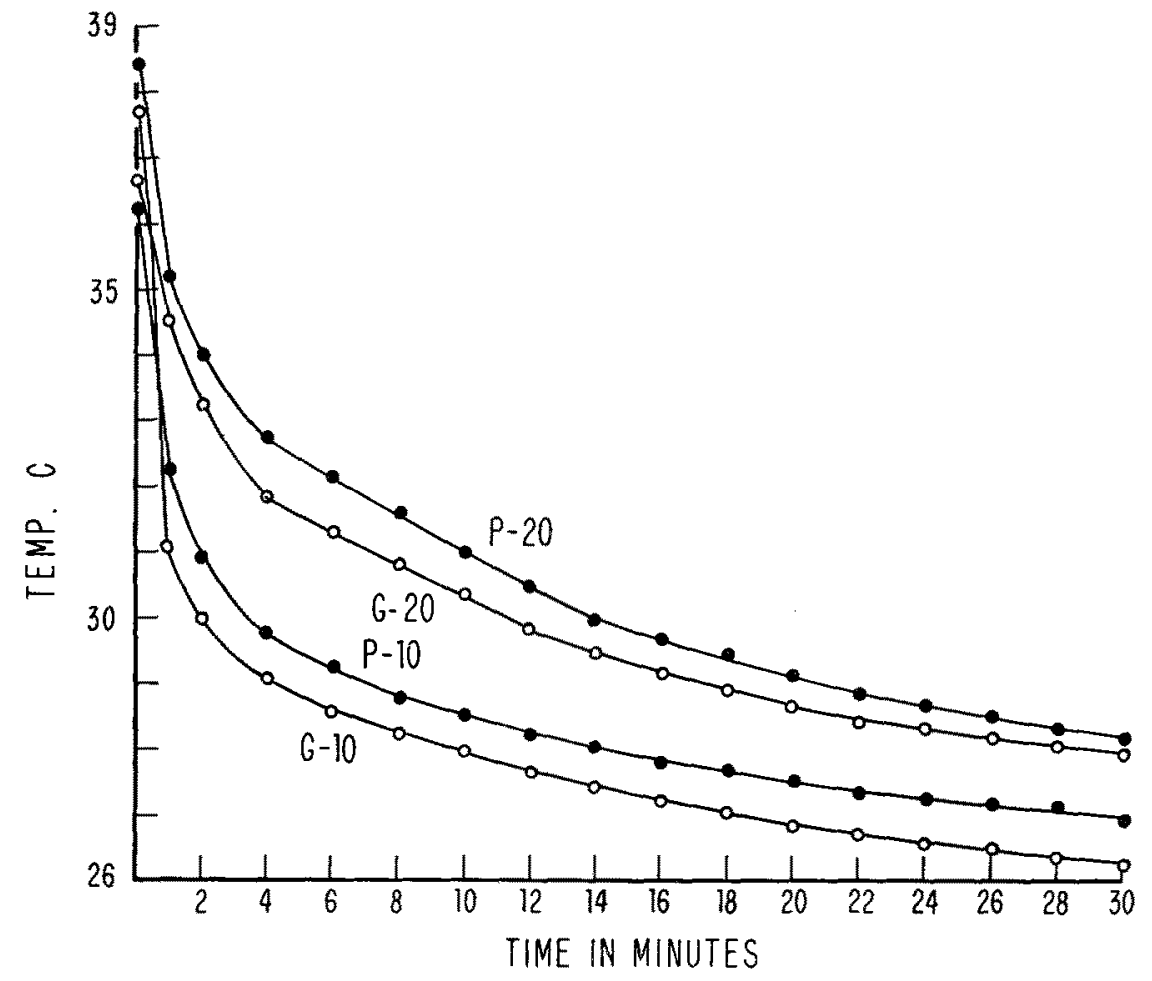

Figure 3. Temperature of nutrient agar after different periods of time when either 10 or $20 \mathrm{ml}$ was poured at $42^{0} \mathrm{C}$ into pyrex glass $(G)$ Petri dishes, or into plastic (P) ones

Discussion

The foregoing results show the importance of employing uniform and relatively small $(10 \mathrm{ml})$ volumes of agar medium for plate counts, particularly when working with thermosensitive bacteria. Many marine bacteria are injured by brief exposure to temperatures between $30^{\circ}$ and $42^{\circ} \mathrm{C}$, the latter being the temperature at which agar medium begins to solidify. The injurious effects of temperature are proportional to time of exposure; large volumes of agar medium poured in plates or bottles cool more slowly than small volumes. Nutrient gelatin, which can be plated at $25^{\circ} \mathrm{C}$, might be better than agar medium, plated at $42^{\circ} \mathrm{C}$, were it not for the fact that gelatin is rapidly liquefied by many marine species.

Larger volumes of agar medium in plates result in thicker layers and, consequently, proportionately more bacteria in inocula are deeply embedded in the medium. Most deeply embedded bacteria develop into colonies more slowly than those seeded on or near the surface of solid medium. Tiny buried 


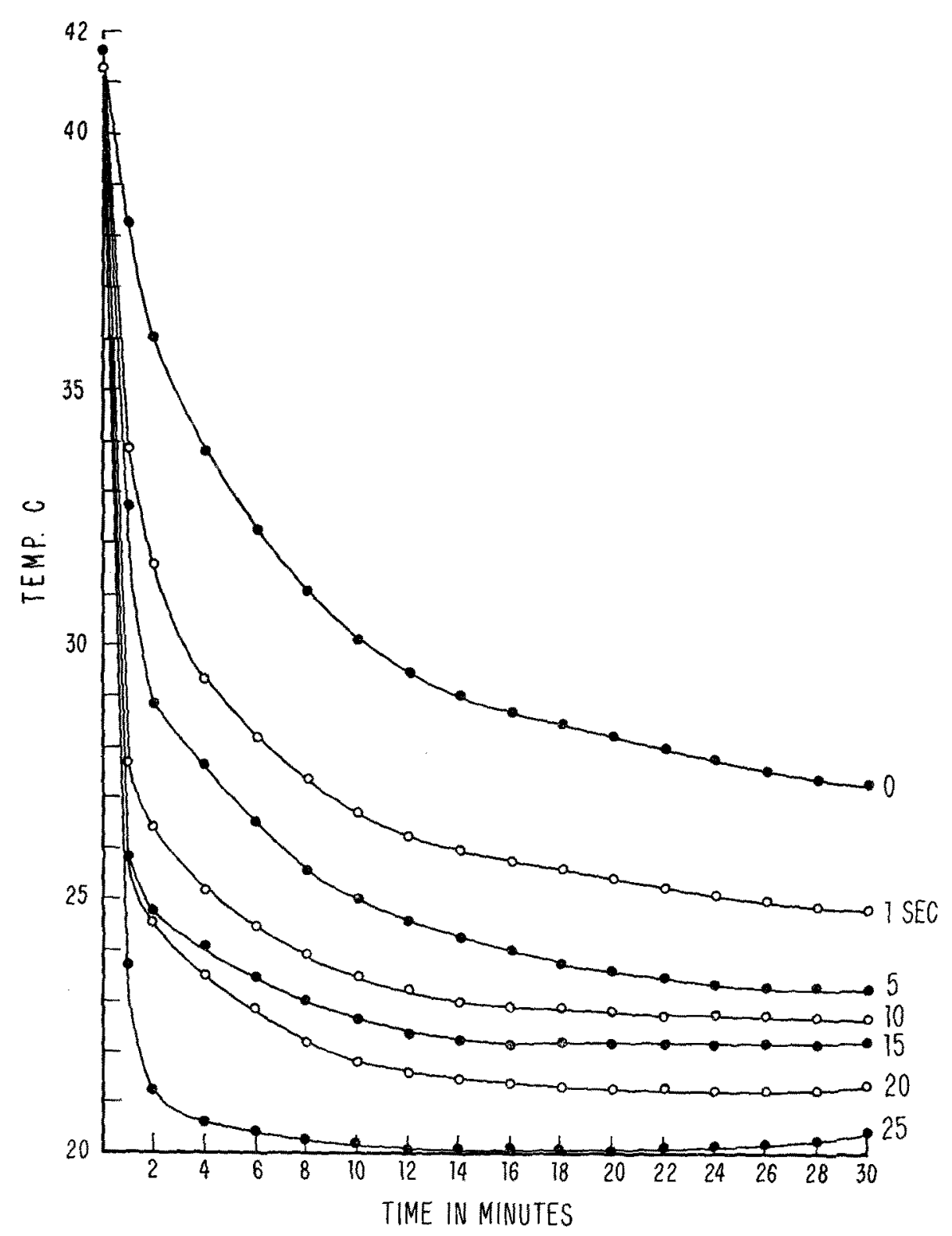

Figure 4. Temperature after different periods of time of $10 \mathrm{ml}$ nutrient agar poured at $4{ }^{\mathrm{g}}{ }^{9} \mathrm{C}$ into 6-oz perscription bottles which were immersed in ice water for 1 to 25 seconds and then placed on side on a polyvinyl table top at $23^{\circ} \mathrm{C}$. The one marked " $\mathrm{O}$ " is the control which was not immersed in ice water

colonies may escape detection by conventional counting procedures. Carluccr and Pramer (1957) also noted that surface colonies of marine bacteria are larger und more uniform in size than those embedded in nutrient agar. However, they found fewer bacterial colonies on surface-inoculated presolidified agar medium than in plates prepared in the conventional way. They attributed this difference to the growth of microaerophilic and anaerobic bacteria below the surface of $15 \mathrm{ml}$ of nutrient agar in pour plates. Using methylene 
blue and other redox potential indicators, we detected no evidence of Eh stratification in $15 \mathrm{ml}$ of uninoculated agar medium in $100-\mathrm{mm}$ Petri dishes. When plates were inoculated with raw sea water to give a few hundred bacterial colonies per plate, reducing conditions were produced in the deeper layers of agar medium, presumably due to the utilization of oxygen by aerobes.

Experiments are in progress at Helgoland to repeat and extend these observations.

\section{Acknowledgments}

The authors wish to express their appreciation to Mrs. Erika Gunkel and Miss Susan Wright for their technical assistance. Special thanks are due to James M. Snodgrass who provided the thermistors and advice for their use. The graphs were prepared by Robert C. Winsett. The work was supported in part by grant E-1768 from the National Institutes of Health, project NR 103-020 of the Office of Naval Research, and funds from the German Government.

\section{Literature}

American Public Health Association, 1960: Standard methods for the examination of water and wastewater including bottom sediments and sludges. Amer. Pub. Health Assoc., Inc., New York, 11 th ed., p. 499.

Carlucci, A. F., and Pramer, D., 1957: Factors influencing the plate method for determining abundance of bacteria in sea water. Proc. Soc. Exper. Biol. Med. 96, 392-394.

Collins, V. G., and Kipling, C., 1957: The enumeration of waterborne bacteria by a new direct count method. J. Appl. Bacteriol. 20, 257-264.

De Moss, R. D., and Bard, R. C., 1957: Physiological and biochemical technics. Manuel of Microbiological Methods of the Society of American Bacteriologists, McGraw-Hill. Co., New York, p. 170.

Jannasch, H. W., 1958; Studies on planktonic bacteria by means of direct membrane filter method. J. Gen. Microbiol. 18, 609-620.

Jannasch, H. W., and Jones, G. E., 1959: Bacterial populations in sea water as determined by different methods of enumeration. Limnol. Oceanogr. 4, 128-139.

Kriss, A. E., 1959: Marine microbiology (deep water). Acad Sci. SSSR, Moscow, 452 pp. (In Russian).

ZoBel1, C. E., 1941: Apparatus for collecting water samples from different depths for bacteriological analysis. J. Mar. Res. 4, 173-188.

- 1946: Marine microbiology: a monograph on hydrobacteriology. Chronica Botanica, Waltham, Mass., $240 \mathrm{pp}$.

- 1959: Introduction to maríne microbiology. New Zealand Oceanogr. Inst. Mem. 3, 7-23.

ZoBel1, C. E., and Conn, J. E, 1940: Studies on the thermal sensitivity of marine bacteria. J. Bacteriol. 40, 223-238.

ZoBell, C. E., and Upham, H. C., 1944: A list of marine bacteria including descriptions of sixty new species. Bull. Scripps Inst. Oceanogr. 5, 239-292. 